MARIA PASZTOR

Faculty of Political Science and

International Sudies, University of Warsaw

\title{
A CIRCLE OF IMPOSSIBILITY. THE PROBLEM OF DISARMAMENT, DÉTENTE AND SECURITY IN POLISH-ITALIAN RELATIONS (1958-1969)*
}

\begin{abstract}
The article is an analysis of the attitude within the circles of the Italian Republic to Poland's disarmament plans in 1958-69, that is the Rapacki Plan (1958) and the Gomulka Plan (1963). Drawing on Italian documents the author examines the attitude of the Italian government to these proposals. She presents the determinants and contexts of both proposals (the bipolar division of the world during the Cold War, Italy's membership of NATO and subordination to Washington's policy, the country's economic and financial problems). The article also contains opinions on Moscow's role in and attitude towards the Polish peace initiatives.

Ke y w ord s: disarmament, Rapacki Plan, Gomułka Plan, Cold War, Polish-Italian relations.
\end{abstract}

In the late 1950s, despite increasing efforts to attain greater political independence within the Western Bloc, successive Italian governments were reluctant to support disarmament proposals promoted by Warsaw between 1957-59. ${ }^{1}$ Italian politicians regarded détente between the USA and

${ }^{*}$ The author wishes to express her gratitude to the Lanckoroński Foundation for granting her a scholarship to conduct research in Italy.

${ }^{1}$ The Rapacki Plan was presented on 2 October 1967 by Poland's Minister of Foreign Affairs Adam Rapacki during the 12th session of the UN General Assembly. It provided for the establishment of a nuclear-free zone in Central Europe encompassing the territories of Czechoslovakia, the German Democratic Republic, Federal Republic of Germany and Poland. The Polish government formally submitted its proposal (with Moscow's permission), in the form of a memorandum, to the governments of the four powers as well as those of Czechoslovakia, German Democratic Republic, Federal Republic of Germany, Belgium, Denmark, Holland, Luxembourg and Canada. The Rapacki Plan, its origins and 'provenance' as well as various countries' attitudes to it have been discussed by for example Piotr S. Wandycz, 'Adam Rapacki and the European Security', 
the USSR as dangerous and potentially leading to an agreement between the superpowers without the involvement of smaller European countries. In their view the process could also have limited the American military and economic presence on the continent (especially on the Italian Peninsula), which, as a majority of the Italian political establishment believed, would have put the country at risk of political instability, enabling the Italian Communist Party to seize power. ${ }^{2}$ Hence the Italian government's consent in 1958 to the placement in Italy of launchers for nuclear-tipped medium-range missiles (Jupiter). ${ }^{3}$ The prevailing opinion among Italian politicians and diplomats was that the most important political decisions depended, in fact, on the USA and the USSR, and that Italy was forced to accept them. ${ }^{4}$

Such considerations made the circles within Italian government reluctant to become involved in the so-called 'détente initiatives'. Nor could Italy accept solutions that would reduce the political and military weight of an important (primarily in economic terms) partner of Rome, West Germany. ${ }^{5}$ That is why despite their efforts Polish diplomats were unable to obtain Rome's support for the Rapacki Plan on an international level. It is

in The Diplomats 1939-1979, ed. Gordon A. Craig and Francis L. Loewenheim, Princeton, NJ, 1994, pp. 298-339; Teresa Łoś-Nowak, Plan Rapackiego a bezpieczeństwo europejskie, Wrocław, 1991; Jacek Tebinka, 'Dyplomacja popaździernikowa (1957-1960). 1. Plan Rapackiego', in Historia dyplomacji polskiej, 6 vols, Warsaw, 1980-2010, vol. 6: 1944/45-1989, ed. Wojciech Materski and Waldemar Michowicz, pp. 468-80; Andrzej Skrzypek, Mechanizmy autonomii. Stosunki polsko-radzieckie 1956-1965, Pułtusk and Warsaw, 2005, pp. 148-52; Jakub Tyszkiewicz, Rozbijanie monolitu. Polityka Stanów Zjednoczonych wobec Polski 1945-1988, Warsaw, 2015, pp. 147-49; Krzysztof Ruchniewicz, Warszawa - Berlin Bonn. Stosunki polityczne 1949-1958, Wrocław, 2003, pp. 332-60; Beatrice Heuser, NATO, Britain, France and the FRG. Nuclear Strategies and Forces for Europe, 1949-2000, London and New York, 1997, pp. 126-27; Piotr Madajczyk, 'Próby wznowienia Planu Rapackiego przez dyplomację polską w pierwszej połowie lat sześćdziesiątych', Rocznik Polsko-Niemiecki, 17, 2009, pp. 11 ff.; Piotr Długołęcki, 'Nieznany kontekst planu Rapackiego', Sprawy Międzynarodowe, 64, 2011, 1, pp.116-127.

${ }^{2}$ For the opinion of successive Italian governments on the Rapacki Plan, see Maria Pasztor and Dariusz Jarosz, Skazani na podległość. Z dziejów stosunków polsko-włoskich w latach 1945-1958, Warsaw, 2013, pp. 94-101.

${ }^{3}$ Giuseppe Mammarella, L'Italia contemporanea 1943-2007, Bologna, 2008, p. 232.

${ }^{4} 10$ April 1958, note by the embassy in Rome on Polish-Italian relations and Italy's foreign policy, in Polskie Dokumenty Dyplomatyczne, 1958, ed. Dariusz Jarosz and Maria Pasztor, Warsaw, 2011, doc.121, p. 271. Such an opinion, characteristic of these circles, was expressed by Francesco Cavalletti, director of the Press Office at the Palazzo Chigi, in a conversation with Marian Wielgosz, first secretary of the embassy.

${ }^{5}$ Grażyna Bernatowicz believes that the negative attitude of the Italian government to the Rapacki Plan stemmed from its solidarity with West Germany. See Grażyna Bernatowicz, Stosunki polsko-włoskie 1944-1989, Warsaw, 1990, p. 76. For more on West Germany's attitude towards the Rapacki Plan, see Ruchniewicz, Warszawa - Berlin - Bonn, pp. 332-56. 
also why the Rapacki Plan was rejected during a debate in the Italian parliament devoted to foreign policy (5 February 1958) by the then Minister of Foreign Affairs and Deputy Prime Minister, Giuseppe Pella. The politician concluded that although from a military point of view the plan was of no great significance, in political terms it would lead to a gradual weakening of Central Europe by [strengthening] the division of Germany, and that its objective was to bring about a break-up of NATO. ${ }^{6}$ During an interdepartmental meeting (24 March 1958) to prepare on Italy's position for the next NATO summit, decision makers from the Italian Ministry of Foreign Affairs stressed that all disarmament proposals (including Italian proposals) had to be within the framework of a 'positive solution of the German problem' [that is future unification of Germany - M.P.] and could not diminish NATO's defence potential. The Rapacki Plan definitely fell outside this framework. According to the Italian Chief of Staff, the plan 'in itself did not bring a serious risk' but in political terms it should be treated with 'utmost caution'. In the view of the Palazzo Chigi, in addition to 'averting the problem of Germany's unification' by potentially creating a nuclear-free zone in Central Europe, the plan would have had a propaganda effect in favour of 'socialist countries' (it would have constituted a precedent attracting many other countries). The government circles perceived the greatest danger not in the military context, but in the political and propaganda effects of the plan. In their view, the Rapacki Plan would have been the first step towards loosening obligations within NATO.?

That is why despite Warsaw's efforts it proved impossible to enter into serious dialogue with the Italian government about the so-called Rapacki Plan, which successive Italian governments saw as a means to consolidate the territorial possessions of the Eastern Bloc (including, in particular, of communist Poland, whose border on the Rivers Oder and Neisse was until 1970 recognized only by the German Democratic Republic). ${ }^{8}$

\footnotetext{
${ }^{6}$ For more on the topic, see Pasztor and Jarosz, Skazani na podległość, pp. 96-98.

${ }^{7}$ Archivio del Ministero degli Affari Esteri (Rome), (hereafter: AMAER), Direzione generale Affari Politici, Uff. IV 1963/64, Polonia, versamento II, pacco [carton] 8. Appunto, Roma, 25 marzo 1958, no pagination. 'In tale occasione e' risultato che, dal punto di vista strettamente militarne, ad un primo esame, il piano [Rapacki - M.P.] non comporta in se' stesso i gravi rischi. [...] La costituzione di una "zona a statuto speciale" nel centro dell'Europa, rappresenta in realta' un allontamento dalla posizione, fin qui rigidamente mentenuto, e cioè che il problema della riunificazione tedesca e' indissolubimente legato. [...] La costituzione di una "zona" si fatta presenta il rischio di dar vita ad un precedente e ad un esempio di essercitare una notevola forza di attrazione nei confronti di un numero sempre maggiore di paesi'.

${ }^{8}$ Pasztor and Jarosz, Skazani na podległość, p. 95. According to authors of literature
} 
In 1959-62 the negative attitude of Italy (like that of France and the United Kingdom) to the concept of a limited armament zone and to the Rapacki Plan (as well as its new version) did not change. However, in view of the disarmament talks in Geneva (15 March 1960) and a meeting of foreign affairs' ministers from Western countries in Washington (12-14 April 1960) ${ }^{9}$ seeking to formulate a common position before the East-West conference in Paris (planned for May 1960), this did not prevent Rome from adopting a more conciliatory stance on the Polish proposals. Yet it stemmed more from a change of tactics than from a change in Rome's attitude to the essence of these proposals. Antonio Segni's and Ferdinando Tambroni's Christian Democratic governments, fearful for their country's isolation on the international stage, saw participation in disarmament discussions as an opportunity to strengthen Italy's activity and prestige within the North Atlantic Alliance. ${ }^{10}$ Some part may have also been played by a desire to deprive the Italian Communist Party and the left wing of the Italian Socialist Party of their propaganda monopoly on détente and the denuclearization of Italy. ${ }^{11}$

Although the international situation deteriorated after the failed American-Soviet summit in Paris in May 1960 and then during the Berlin and Cuban crises in 1961-62, and although power in Italy was taken over by the Christian Democrat Amintore Fanfani's centre-right government (involving the Christian Democrats, Republicans, Social Democrats and supported by the Socialists), the attitude of successive governments

on the subject, the source of this initiative was to be found in Warsaw's concerns over West Germany gaining access to nuclear weapons, and in Władysław Gomułka's hope for détente in relations with the West. See Jacek Tebinka, Nadzieje i rozczarowania. Polityka Wielkiej Brytanii wobec Polski 1956-1970, Warsaw, 2005, p. 84; Robert Kupiecki, Siła i solidarność. Strategia NATO 1949-1989, Warsaw, 2012, pp. 191-92.

${ }^{9}$ For more on the United Kingdom's attitude to the Rapacki Plan, see Tebinka, Nadzieje i rozczarowania, pp. 58-105. See also Georges-Henri Soutou, La guerre de Cinquante Ans. Les relations Est-Ouest 1943-1990, Paris, 2001, pp. 377-80; Maria Pasztor, 'Francja i Wielka Brytania wobec polskich koncepcji rozbrojeniowych 1957-1964', DN, 35, 2003, 1, p. 108.

${ }^{10}$ The Italian Christian Democrats were critical of the Rapacki Plan. See Pasztor and Jarosz, Skazani na podległość, p. 100. Italy's ambitions are evidenced by President Giovanni Gronchi's visit to the USSR in early 1960. Gronchi's talks with Nikita Khrushchev about international affairs ended in a spectacular loss of prestige for the Italian delegation. See Giuseppe Mammarella and Paolo Cacace, La politica estera dell'Italia. Dallo Stato unitario ai giorni nostri, Rome and Bari, 2010, p. 213.

${ }^{11}$ The Italian Communist Party and the left wing of the Italian Socialist Party supported the Rapacki Plan in Italy. They advocated the introduction of a nuclear-free zone in Italy. For more on the topic, see Pasztor and Jarosz, Skazani na podległość, pp. 99-100. 
to the Rapacki Plan and its variants was not in essence revised. ${ }^{12}$ Italy presented its position at the Eighteen Nation Conference on Disarmament (ENCD), which resumed its sessions in Geneva (14 March 1962). ${ }^{13}$ This time the Palazzo Chigi concluded that a categorical rejection of the Rapacki Plan would not be advisable for strategic reasons, especially given the fact that such an attitude - as was believed in Rome - would have placed Italian diplomacy outside the international mainstream.

Thus in a paper prepared for the ministry, the Polish plan was officially acknowledged as a starting point for a broader discussion about détente and Italian diplomats were encouraged to become actively involved in discussions preceding the Geneva conference. The Rapacki Plan or, rather, Italy's critical attitude to the concept could to some extent justify Rome's efforts to assume a more significant role in NATO. Formulating its own position on the Polish plan and the so-called détente problems could not only help Italy to affirm its participation in the Geneva conference, but also become a starting point for pursuing more ambitious goals (especially after France's refusal to take part in disarmament talks). ${ }^{14}$ It is, therefore, not surprising that in its position for the government, the Italian Ministry of Foreign Affairs stressed the need to change strategy in the matter and recommended the adoption of a more active approach during the ongoing discussions regarding disarmament (including the Rapacki Plan): 'our legitimate insistence on full participation in all stages of preparatory work before a future East-West meeting [in Geneva in March 1962 - M.P.] and in the meeting itself will be all the more justified if we prove our ability to make a significant contribution' [to the work of the conference - M.P.]. This was recommended, as was claimed, to Italian diplomats in the most important capital cities. ${ }^{15}$

The change in Italian tactics with regard to Polish disarmament plans did not, in fact, mark a change in the opinion of Italian diplomatic and government circles, as is evidenced by their negative reception of

${ }^{12}$ Mammarella and Cacace, La politica estera dell'Italia, p. 123.

${ }^{13}$ On 14 March 1962 the ENCD resumed its session and the Polish delegation presented a modified version of the Rapacki Plan (creation of a nuclear-free zone in Central Europe and limited armament). Soutou, La guerre de Cinquante Ans, p. 399; see also Heuser, NATO, Britain, France, pp. 126-27.

${ }^{14}$ France, busy during Charles de Gaulle's presidency with building its own nuclear force de frappe, withdrew from the work of the ENCD. See Soutou, La guerre de Cinquante Ans, p. 426. Cf. Kupiecki, Siła i solidarność, pp. 185-86, 190.

${ }^{15}$ AMAER, Direzione generale Affari Politici, Uff. IV 1963/64, Polonia, pacco 8. Il vice-Direttore Generale degli Affari Politici, Appunto per il Gruppo Disarmo DGAP, Roma, il 15 febbraio 1962, no pagination. 
the third version of the Rapacki Plan presented at the ENCD in Geneva (28 March 1962) by the Polish delegation. ${ }^{16}$

Rome realized very well that the new variant of the so-called Rapacki Plan did not bring any significant technical changes to its previous version and came down to building a 'non-involved zone' in Central Europe, posing the same (as in the previous versions) threats to Western Europe (that is a weakening of NATO). The Polish plan did provide for the elimination of means for transferring nuclear weapons and for the freezing of nuclear potential and its subsequent elimination, yet in the view of the Italian experts it did not take into account reservations on the part of NATO countries, especially West Germany. ${ }^{17}$ The same view had the Rapacki Plan as primarily a means to solve the problem of Poland's western border..$^{18}$ Documents of the Italian Ministry of Foreign Affairs stressed that the Polish position adopted during the disarmament discussion at the Geneva conference in the summer of 1962 was, in fact, identical to the Soviet position, with differences between the two delegations essentially coming down to the 'adoption [by the Poles] in the debates of a less rigid stance that was normally characteristic of contributions by delegates from communist countries'. According to the same officials, the differences apparently stemmed from Polish diplomats' considerations of ambition and prestige. In the opinion of the Italian Ministry of Foreign Affairs, these ambitions were 'often demonstrated by the Warsaw government after 1956 [and were motivated] by a desire to stand out, if only seemingly, among the monotonous chorus of other satellites of the USSR'. ${ }^{19}$ This, however, did not prevent Italian diplomats from attempting to exploit the Rapacki Plan in the pursuit of personal objectives.

${ }^{16}$ For more on the successive versions of the Rapacki Plan, see Teresa Łoś-Nowak, Polskie inicjatywy w sprawie broni nuklearnej w Europie środkowej 1957-1964, Wrocław, 1989; Wandycz, 'Adam Rapacki and the European Security', pp. 289-317; James R. Ozinga, The Rapacki Plan. The 1957 Proposal to Denuclearise Central Europe, and an Analysis of Its Rejection, Jefferson, NC, and London, 1989; Fulvio D'Amoja, 'Piano Rapacki e rapporti fra i due blocchi', La Comunità Internazionale, 14, 1959, 4, pp. 604-25; Ulrich Albrecht, 'The Political Background of the Rapacki Plan of 1957 and Its Current Significance', International Journal of Politics, 13, 1983, 1/2, pp. 117-33.

${ }^{17}$ AMAER, Direzione generale Affari Politici, Uff. IV 1963/64, Polonia, versamento II, pacco 8. MAE, Direzione Generale degli Affari Politici, Appunto per il Gruppo Disarmo DGAP, Roma, il 13 marzo 1963, no pagination.

18 'Il piano Rapacki costituisce communque argomento di ricorrente preoccupazioni che suscitano in Polonia la questione delle sue frontiere occidentali'. Particularly strong reservations, according to an apt observation by the Italians, were formulated with regard to the Rapacki Plan by West Germany, ibid.

19 'Ulteriore manifestazioni dell'aspirazione, spesso montata dal governamento di Varsavia, sin dai noti avvenimenti dell'ottobre 1956 in Polonia, a distinguersi, sia pure solo apparentemente, dal monotono coro degli altri satelliti comunisti', ibid. 
The initially cautious attitude of Prime Minister Fanfani's centre-left government towards President John Kennedy's proposal to build a multilateral nuclear force (MLF) involving West Germany (in early 1963) in conjunction with the American deterrence policy ${ }^{20}$ was in fact dictated by the upcoming (May 1963) parliamentary elections and concern about tension between the Christian Democrats and the Socialists over the matter (which would hinder their cooperation after the elections). The latter were against giving West Germany access to nuclear weapons. The electoral calculations of Italian politicians and removal from the Italian Peninsula of Jupiter missile launchers ${ }^{21}$ raised hopes in Warsaw that the Italian government would become more independent (from Washington) and more favourable towards disarmament.

These considerations may have been the source of Warsaw's signals indicating its willingness to enter into a dialogue through direct talks with Rome. An opportunity to exchange ideas in the matter came with an official visit by Prime Minister Józef Cyrankiewicz to Italy in the summer of 1963.

However, Cyrankiewicz's talks with Deputy Prime Minister and Foreign Secretary Attilio Piccioni and Prime Minister Fanfani did not lead to a rapprochement between the two sides in terms of their respective positions on détente and the limitation of armament. The Polish side's hopes that the Italian government would adopt an independent stance could not become reality, as was confirmed by Cyrankiewicz's meetings with Italian politicians. The talks were essentially a presentation of the opinions of the two governments or, rather, two opposing blocs. Piccioni limited himself to an enigmatic statement concerning 'special interest in the problem of

${ }^{20}$ Work on and discussions about the creation of a nuclear force by the allies began, according to Robert Kupiecki, in the late 1950s, and were a response to the growing potential of Soviet nuclear medium-range weapons as well as an attempt at a more sustainable division of tasks associated with deterrence policy, which was at the core of the MLF. As Kupiecki writes, the proposal would have enabled NATO countries to build a sense of participation in strategic decision-making and would have given the USA 'a sense of control over the process'. Another possibility was the American offer, submitted towards the end of 1960, to assign five submarines with the Polaris missiles to NATO as the beginning of the MLF. There were also discussions about expanding a jointly financed fleet equipped with 200 missiles of this type. See Kupiecki, Siła i solidarność, pp. 189-91; David N. Schwartz, 'The Role of Deterrence in NATO Defense Strategy. Implications for Doctrine and Posture', World Politics, 28, 1975, 1, pp. 118-33.

This did not prevent the Italians from expressing their approval of the creation of a multilateral nuclear force after the 1963 elections and then joining NATO's Nuclear Planning Group in 1966. See Bernatowicz, Stosunki polsko-włoskie, p. 132.

${ }^{21}$ Mammarella and Cacace, La politica estera dell'Italia, p. 218. 
disarmament and some rapprochement that could be achieved between Poland and Italy at the Geneva Disarmament Committee'. The Italian Foreign Secretary stressed foremost his country's interest in a global disarmament that should be initiated by the USSR and the USA. He suggested (via Warsaw) a modification in the USSR's stance on suspending nuclear weapon experiments and, especially, on the frequency of inspections [conducted by international experts] of nuclear test sites that should be subject to a compromise between the two superpowers. ${ }^{22}$

The position of the Polish Prime Minister on this matter came down to promoting the Rapacki Plan as a partial solution, limited to a nuclear-free zone in Europe - a solution that, as he concluded, was an element in and first step towards global disarmament (in his view, the situation had not yet reached the point when it could be achieved as advocated by the Italians). ${ }^{23}$ According to the Polish Prime Minister, the achievement of this goal could be facilitated by the signing of a non-aggression pact between NATO and the Warsaw Pact (which Poland proposed, following Moscow's example).$^{24}$ Cyrankiewicz did not hide the fact that when talking about a nuclear-free zone in Europe, he was thinking about the German problem and was 'concerned' about Germany having nuclear weapons. ${ }^{25}$ The Italian minister did appear to 'appreciate the attractive aspects' of the Rapacki Plan, but claimed that from the Italian perspective the suspension of nuclear weapon tests was a crucial matter, more important than the creation of a nuclear-free zone, but remained unfortunately at a preliminary stage.

${ }^{22}$ Archivio Centrale dello Stato, Rome (hereafter: ACS), Ufficio del Consigliere Diplomatico 1949-1963, no. H44, Visita in Italia del Presidente del Consiglio dei ministri polacco, Józef Cyrankiewicz, Roma, 15 marzo 1963, ore: 19:30 [min. A. Piccioni]; ibid., P. Vinci, capo del gabinetto del Ministro degli Affari esteri al Consigliere Diplomatico del Presidente del Consiglio dei Ministri, C. Marchiori, Possibili temi di conversazione col Presidente del Consiglio dei Ministri, Cyrankiewicz, Roma, 13 marzo 1963, no pagination. Piccioni: 'A tale riguardo assume un particolare interesse il problema del disarmo per il quale qualche accostamento tra Italia e Polonia, che entrambi fanno parte del comitato di Ginerva, potrebbe essero trovato'. The minister's stance was in line with an earlier suggestion by Piero Vinci, chief of staff at the Ministry of Foreign Affairs, also passed to the Prime Minister Fanfani's diplomatic adviser, Carlo Marchiori. Vinci suggested closer cooperation between the Polish and the Italian delegations in Geneva in order to persuade Moscow to abandon its 'sterile attitude' and start discussing the technical measures to be used to verify the frequency of inspections of nuclear test sites.

${ }^{23}$ Ibid. [Cyrankiewicz].

${ }^{24}$ A non-aggression pact was proposed at the UN Disarmament Commission by the USSR on 20 February 1963, Soutou, La guerre de Cinquante Ans, p. 425-27.

${ }^{25}$ ACS, Ufficio del Consigliere Diplomatico 1949-1963, no. H44, Visita in Italia del Presidente del Consiglio dei ministri polacco, Józef Cyrankiewicz, Roma, 15 marzo 1963, ore: 19:30 [Cyrankiewicz], no pagination. 
As a result of this last assertion the atmosphere of the discussion deteriorated considerably; the Polish side, clearly disappointed at a lack of understanding for its proposals, blamed Washington for a crisis of trust (in the context of the Cuban Crisis). In addition, the Poles argued that it was the Americans, demanding 'an excessive number of nuclear site inspections', who brought about the crisis in disarmament negotiations. Another controversy, separate from the Cuban problem (or, rather, the question of who was to be blamed for the escalation of tension), centred around the issue of American bases in which missile launchers were located. The position of the Polish delegation was firmly rejected by the Italians, who left their interlocutors in no doubt as to their attitude to the Rapacki Plan, and ultimately (contrary to their initial statements) the prospects of establishing closer cooperation within the framework of the Disarmament Committee. ${ }^{26}$

No new developments were added by a short conversation between Cyrankiewicz and Prime Minister Fanfani on 15 March $1963 .{ }^{27}$ The talks in Rome showed that on the international stage, where the most important decisions were taken by the two superpowers, room for manoeuvre for small and medium-sized states was very limited indeed and that their initiatives, especially in areas as important as disarmament and détente or the German question, stood no chance of being implemented.

Meanwhile, the aftermath of the Cuban Crisis and the East-West confrontation the period of 1963-64 saw an easing of tension between the two blocs. It comprised the withdrawal of the Soviet missiles from Cuba, a change in the USA's strategy with regard to communist countries (a strategy of peaceful engagement in Eastern Europe) as well as a more conciliatory attitude of Moscow to the West, dictated by its conflict with China and a worsening economic situation in the USSR. This led to the signing of an agreement between the USA, United Kingdom and USSR on a partial nuclear test ban in the atmosphere and under water (5 August 1963). ${ }^{28}$

A favourable international situation as well as a truce between political parties in Italy enabled Giovanni Leone's Christian Democratic government, after the spring 1963 elections, to undertake stabilizing actions inside the country and gave it more freedom to pursue its foreign policy. ${ }^{29}$

${ }^{26}$ Ibid. [Cyrankiewicz, Piccioni, Naszkowski].

${ }^{27}$ Ibid. [Cyrankiewicz, Fanfani].

${ }^{28}$ Soutou, La guerre de Cinquante Ans, pp. 425-41. The ban did not apply to underground nuclear tests, as these explosions could not be controlled at the time. See ibid., p. 426.

${ }^{29}$ Mammarella, L'Italia contemporanea, p. 281. 
However, this did not translate into a change in the approach to the problem of disarmament, all the more so given the fact that Italy (after the fiasco of the French-Italian-German talks of 1957-58) had no nuclear ambitions. $^{30}$

The Italian government did join the treaty of 5 August 1963, but in the end it also expressed its support for the idea of establishing a multilateral nuclear force (MLF) ${ }^{31}$ Italy's policy in this area was marked by inconsistency and was clearly outside the sphere of autonomous decision-making. Dependent on the American policy and fearing negative reactions from West Germany, ${ }^{32}$ Italian diplomats had no intention of becoming involved in enterprises doomed to failure and of adopting positions different from those of Washington. This stood in contrast with Władysław Gomułka's attitude to the MLF idea. From the very beginning the Polish politician was vehemently opposed to equipping the Bundeswehr with nuclear weapons, or indirectly providing West Germany with access to such weapons by handing them to the supranational NATO forces stationed in West Germany. ${ }^{33}$

${ }^{30}$ Mammarella and Cacace, La politica estera dell'Italia, p. 223. On the French-Italian-German agreements on nuclear weapon cooperation (of 28 November 1957 and 8 April 1958) see Georges-Henri Soutou, L'alliance incertaine. Les rapports politico-stratégiques franco-allemands, 1954-1996, Paris, 1996, pp. 110-39; idem, 'Les accords de 1957 et 1958: vers une communauté stratégique et nucléaire entre la France, l’Allemagne et l'Italie?', Matériaux pour l'Histoire de notre Temps, 31, 1993, pp. 1-12; Stephan Mourlane, 'La France, l'Italie et la construction européenne: le temps des malentendus (1958-1965)', Relations internationales, 118, 2004, pp. 200-12.

${ }^{31}$ During a visit to Rome by West Germany's Chancellor Ludwig Erhard and Foreign Secretary Gerhard Schröder (in January 1964) the Italians again expressed their support for the creation of the MLF. See Archiwum Ministerstwa Spraw Zagranicznych (hereafter: AMSZ) 23/69, Embassy of the Polish People's Republic in Rome, A. Willmann to Head of Dep. IV, Ministry of Foreign Affairs, Mieczysław Łobodycz, Rome, cable of 30 January 1964.

${ }^{32}$ At that time Italy sought a rapprochement with West Germany, wanting to provide a counterbalance to the alliance between France and West Germany based on the Élysée Treaty of 1963. West Germany was Italy's most important trade partner. See Mourlane, 'La France, l'Italie et la construction européenne', pp. 209-10.

${ }^{33}$ W. Gomulka was opposed to the MLF idea, an attitude he expressed in a letter to N. Khrushchev on the 8th of October 1963. According to Gomułka's account, Khrushchev allegedly tacitly agreed to the creation of the MLF, concluding that 'this does not change the balance of power between the socialist camp and the Atlantic alliance' and that the MLF 'may prevent West Germany from building its own national nuclear force'. See doc. no. 21, Władysław Gomułka's report on the meeting with the Soviet delegation in Białowieża on 24 October delivered during the second plenum of the Central Committee of the Polish United Workers' Party in November 1964, in Tajne dokumenty Biura Politycznego PRL-ZSRR 1956-1970, introduction Andrzej Paczkowski, London, 1998, p. 250; see also ibid., W. Gomułka's letter to Khrushchev, 8 October 1963, doc. no. 17, p. 170. Cf. interpretations by Piotr Madajczyk, 'Dyplomacja polska w latach 
Similarly (as in the case of the Rapacki Plan), Italy avoided formulating an official position on another Polish initiative, the so-called Gomulka Plan promulgated in Płock (on 28 December 1963) and presented to Western countries (including the Italian Republic) in the form of a memorandum on 29 February 1964, in response to the plan to set up the MLF. ${ }^{34}$

Warsaw hoped for Rome's support for the initiative following a statement on détente by the Italian Foreign Secretary in Aldo Moro's centre-left government, Giuseppe Saragat, presented to the Senate's Foreign Affairs Committee on 7 February $1964 . .^{35}$ However, the statement was clearly contradicted by the same politician speaking in the Italian Chamber of Deputies on 5 March 1964. Saragat's assertion that in the political circumstances at the time Polish proposals could not be regarded as constructive ${ }^{36}$ boded ill for the Polish initiative in Italy, confusing Polish diplomats even further. In any case, Saragat's opinion was identical to that of the Prime Minister, who had had an opportunity to get to know the details of the plan during a visit to Rome by Poland's Minister of Foreign Trade, Witold Trąmpczyński, in February 1964. A document of the Italian Ministry of Foreign Affairs (approved and signed by Prime Minister Moro) placed the Gomułka Plan within the framework of Moscow's strategy and stressed that it was an updated and revised version of the Rapacki Plan, which, at least in its first stage, provided not for a denuclearization of Central Europe, but only a freezing of relations over nuclear weapons between the two blocs. According to the document, the objective of the Gomulka Plan was to make Western Europe abandon the MLF project. ${ }^{37}$

sześćdziesiątych', p. 606; idem, 'Próby wznowienia Planu Rapackiego', pp. 11 ff., and Skrzypek, Mechanizmy autonomii, pp. 272-75; Kupiecki, Siła i solidarność, pp. 193-94; Wanda Jarząbek, Polska wobec Konferencji Bezpieczeństwa i Współpracy w Europie. Plany i rzeczywistość 1964-1975, Warsaw, 2008, p. 17.

${ }^{34}$ Jarząbek, Polska wobec Konferencji Bezpieczeństwa i Wspótpracy, p. 7. The Gomułka Plan is also discussed in detail by Łoś-Nowak, Polskie inicjatywy, pp. 256-75. See also Madajczyk, 'Dyplomacja polska w latach sześćdziesiątych', pp. 605-09. Skrzypek, Mechanizmy autonomii, pp. 271-75. The Gomułka Plan centred around the freezing of nuclear and thermonuclear armament in Poland, Czechoslovakia, the German Democratic Republic and West Germany, which would prevent the Bundeswehr from acquiring nuclear weapons within the framework of the multilateral force.

${ }^{35}$ Atti Parlamentari. Senato. Discussioni. Seduta del 7 febbraio 1964.

${ }^{36}$ Atti Parlamentari. Camera dei Deputati. Discussioni. Seduta del 5 marzo 1964. Statement by G. Saragat (Foreign Secretary) to the Chamber of Deputies on 5 March 1964.

${ }^{37}$ ACS, Aldo Moro, B. 68, Visita del ministro di Commercio estero di Polonia, W. Trąmpczyński, (Visto dal presidente del Consiglio dei ministri), Roma, 13 febbraio 1965. Appunto del MAE: 'Il nuovo piano polacco di disarmo, e versione aggiornata e riveduta del Piano Rapacki’. 
Yet in view of an emerging rapprochement between the Socialists and the Social Democrats in Italy, the Polish embassy in Rome still hoped for a more favourable attitude of the Italian government to the Gomułka Plan. According to the embassy, speaking in favour of a more conciliatory attitude by Italian government circles were, for example, the "prospects for a union' between the Socialists and Social Democrats as well as the need to eliminate differences between the two in both the country's internal and its foreign policy. ${ }^{38}$

The Polish embassy did point to differences in the approach to the problems of disarmament (within Moro's government) between the Deputy Prime Minister, Socialist Pietro Nenni, and the Foreign Secretary Saragat, but it suggested that a consensus was possible in a form desired by Warsaw. ${ }^{39}$ All the more so given the fact that Nenni, as the Polish ambassador put it, 'spoke in favour of nuclear-free zones' and that relations between Saragat (who was against partial disarmament plans) and Nenni in the context of cooperation between the two parties 'were becoming increasingly conciliatory'. ${ }^{40}$

It is, therefore, not surprising that the Polish embassy in Rome, supported by diplomats from other communist countries (for example Czechoslovakia's ambassador in Rome, Ján Bušniak), took steps to persuade the Italian Ministry of Foreign Affairs to adopt an official stance on the Gomułka Plan. However, the Italians, citing the need to 'study the Polish project in detail', delayed presenting their position on its contents. ${ }^{41}$

The hopes for a rapprochement with Italy in the matter of détente were finally shattered by an official reply to the Gomulka Plan in the form of a 'Memorandum of the Government of the Italian Republic', presented

${ }^{38}$ Mammarella, L'Italia contemporanea, p. 297; Józef Andrzej Gierowski, Historia Włoch, Wrocław, 1985, p. 667. It was not until 1965 that a congress of the Socialist Party passed a resolution on a union with the Social Democrats, with the foundations of the agreement between the two parties being established in July 1966 . The two parties united in October 1966.

${ }^{39}$ AMSZ, Minister's Cabinet, zespół (hereafter: file) 26, wiązka (hereafter: bundle) 6, teczka (hereafter: folder) 50, Study by the Embassy of the Polish People's Republic in Rome. Saragat's attitude to disarmament, especially partial solutions, including the Gomułka Plan, Rome, 18 June 1964. Saragat was in favour of a balance of power between the two blocs. Maintaining that balance in his view was predicated on maintaining nuclear bases, and nuclear weapon launchers and carriers. According to the embassy, Saragat's attitude to the proposal of a non-aggression pact between NATO and the Warsaw Pact was not negative.

${ }^{40}$ Ibid.

${ }^{41}$ AMSZ 23/69, A. Willmann to M. Łobodycz, Rome, cable of 26 May 1964. 'When it comes to Bušniak's proposal,' wrote Willmann, 'for Italy to support our plan of a freeze zone, the foreign minister, G. Saragat, has not taken a stance', no pagination. 
to Warsaw on 19 June 1964. Contrary to Poland's expectations, the Italian decision makers used this to formulate crucial objections to the project, pointing to the impossibility of solving the problems of security and arms control in Central Europe without referring to the political problems of the region (that is the question of unification of Germany). ${ }^{42}$ This was a matter of prime importance to Poland, especially given the fact that the Italians realized, as in the case of the Rapacki Plan, that the Gomułka Plan was yet another attempt by the Polish People's Republic to consolidate its territorial status quo (that is its western border). ${ }^{43}$

In their Memorandum of 19 June the Italians stressed that the proposals presented in the plan (this time freezing of only nuclear missiles located in the nuclear-free zone) would 'prevent a possible development of a local element of the Western Bloc's defence system'. The conclusion was that this would provide for freedom in the modernization and expansion of the Eastern Bloc's arsenal, disrupting the 'delicate equilibrium'. The lack of an appropriate control system in the project would, in the opinion of the Farnesina (the headquarters of the Italian Ministry of Foreign Affairs), give the Eastern Bloc a considerable advantage in armament. ${ }^{44}$ These arguments did not differ from those sent by other NATO countries in their notes to Warsaw. After all, it was not without reason that in the position of the Italian Ministry of Foreign Affairs presented to Deputy Prime Minister Nenni as early as in May 1963 the director general for political affairs at the ministry indicated that the Memorandum should remain within the boundaries outlined during a meeting of the Atlantic Council on the matter. He stressed that since the draft of the Italian reply (as well as those of the other allied governments) had already been discussed and approved in the Atlantic Council it would have been difficult to discuss the matter again. ${ }^{45}$

${ }^{42}$ AMSZ, file 26, bundle 6, folder 50, Italian Memorandum [of 19 June 1965], no pagination.

${ }^{43}$ AMAER, Direzione Generale degli Affari Politici. Uff. IV 1963/64, pacco 8, no pagination, Appunto per il Gruppo Disarmo DGAP, Roma, il 13 marzo 1963; ACS, Direzione Generale degli Affari Politici, Ufficio II al Consigliere del Presidente dei Ministri, Appunto, Roma, 18 gennaio 1965. 'La Polonia cerca cosi da tempo convergenze con l'Italia in materia dei piani di disarmo e di denuclearizzazione, pericoli del revanscismo tedesco'.

${ }^{44}$ AMSZ, file 26, bundle 6, folder 50, Italian Memorandum [of 19 June 1965], no pagination. See also the draft programme of a visit to Poland by the Minister of Foreign Affairs of the Italian Republic, Mr Giuseppe Saragat (2-5 July 1964). Notes for talks with the Minister of Foreign Affairs of the Italian Republic, G. Saragat.

${ }^{45}$ ACS, Aldo Moro, B. 52, Appunto per l'on. Ministro Nenni, MAE Direttore Generale degli Affari Politici al ministro plenipotenziario Gian Franco Pompei, consigliere diplomatico dei Ministri, Roma, 16 maggio 1964. 
Increased tension between the USA and the USSR, including the intensification of the Vietnam War in 1964-65 (in which another Foreign Secretary in Moro's government, Fanfani, tried, unsuccessfully, to act as a negotiator) ${ }^{46}$ yet again worsened the international climate and diminished interest in regional disarmament projects. That is why, not wanting to lose initiative, Poland put forward (on 14 December 1964) an idea of organizing a pan-European security conference (featuring the USA). The idea was presented at the UN by Minister Rapacki. ${ }^{47}$ It is to this idea (and the Gomulka Plan) that Minister Rapacki in vain tried to win over the Italians, talking to Minister of Foreign Affairs Fanfani, Prime Minister Moro and President Saragat during his brief stay in Rome on his way to Iran and Afghanistan in January 1965 (23-25). Despite declarations of full support for 'détente processes', Fanfani showed no willingness to establish closer collaboration with Warsaw on this matter, stressing fidelity to his alliances, which he saw as a 'guarantee of equilibrium and peace' and pointing out that the 'rapprochement' between Italy and Poland could take place mainly in economic and cultural matters. ${ }^{48} \mathrm{~A}$ similar stance on the issue was adopted by Prime Minister Moro, who did not share Polish concerns over the American concept of a multilateral nuclear force (MLF), which, according to the Polish side, would equip West Germany with nuclear weapons, revise the entire process of détente between the East and the West, and lead to a rejection of collective security plans including the Gomułka Plan. ${ }^{49}$

Despite the worsening climate for Polish disarmament initiatives due to the Vietnam conflict, Polish authorities kept pointing to 'a possibility of continuing the dialogue aimed at facilitating the implementation of the basic plan to freeze nuclear weapons in Europe'. This time it

${ }^{46}$ A similar initiative was undertaken by the Mayor of Florence, Giorgio La Pira, and Fanfani's wife, Bianca Rosa. The initiative, known in Italian historiography as la gaffe vietnamita ended with a dismissal of Fanfani as the Minister of Foreign Affairs (28 December 1965). For more on the Italian initiatives in this area, see Mammarella and Cacace, La politica estera dell'Italia, p. 221; Antonio Varsori, L'Italia nelle relazioni internazionali. Dal 1943 al 1992, Rome and Bari, 1998, p. 178.

${ }^{47}$ Jarząbek, Polska wobec Konferencji Bezpieczeństwa i Wspótpracy, pp. 23 ff. According to G.-H. Soutou, the idea of organizing a security conference, presented by Rapacki, originated in the USSR. Soutou, La guerre de Cinquante Ans, p. 470.

${ }^{48}$ ACS, Aldo Moro, B. 68, MAE, Direzione Generale degli Affari Politici, Ufficio II al Consigliere del Presidente dei Ministri, Conversazioni ministro Fanfani con Rapacki, no pagination, Roma, 25 gennaio 1965.

${ }_{49}$ ACS, Aldo Moro, B. 68, MAE, Ufficio IV, i telegrammi in partenza dal Ministero degli AE a Bonn, Bruxelles, Parigi, Varsavia, segreto, visita del ministro degli Affari Esteri, Rapacki, Roma, 25 gennaio 1965; 'A Roma si prepara il tradimento della NATO', Secolo d'Italia, 27 January 1965, no. 28, p. 3. 
was to be achieved 'through bilateral talks with the various countries'. ${ }^{50}$ Raising the matter with Italian politicians seemed all the more relevant to the Polish side given the fact that the Polish projects were going in a direction similar to that of a proposal, submitted in Geneva (on 29 July 1965) by the Italian Minister of Foreign Affairs, Fanfani, for a unilateral relinquishment of nuclear weapons by non-nuclear states for a specific period. It seems that Poland intended to use this coincidence to establish closer cooperation in matters of security and the economy. ${ }^{51}$ Especially given the fact that the ruling centre-left in Italy (from December 1963 to June 1968) began, according to the Polish Ministry of Foreign Affairs, to look for broader room for manoeuvre in pursuing a more independent foreign policy, as personified by the Christian Democrat Fanfani with his Vatican connections. Italy did remain faithful to the political line of the previous governments (the principle of Atlantic and European solidarity), yet a more flexible stance on the matter was apparently brought about both by economic considerations (a desire to expand the country's cooperation with socialist countries, rivalry with France) and questions of internal policy, as has been mentioned earlier. ${ }^{52}$

In the meantime, proposals put forward by the USA and the USSR at the UN and the ENCD concerning non-proliferation of nuclear weapons pushed the Gomułka Plan into the background..$^{53}$ Having lost its

${ }^{50}$ AMSZ 24/70, Points for talks with the President of Italy, G. Saragat, Warsaw, 6 October 1965; AMSZ 24/70, Mieczysław Stefański, counsellor of the Polish embassy in Rome, to Head of Department IV, M. Łobodycz, Rome, cable of 9 October 1965.

${ }^{51}$ Fanfani's proposal (included in his address to the ENCD on 29 July 1965) was presented in the form of a declaration (14 September 1965). Its assumption was that - if no agreement was reached at the disarmament conference - non-nuclear states would unilaterally relinquish any plans to acquire and produce nuclear weapons for a specified period, after which they would regain their freedom to act, if a relevant agreement had not been concluded in the meantime. The Italian proposal did not generate much interest. The Eastern Bloc countries did not adopt an official position on the matter. AMSZ 24/70, Head of Dep. IV, M. Łobodycz to Ambassador A. Willmann, Warsaw, 19 June 1965. Łobodycz told Willmann to inform Fanfani that the Polish Ministry of Foreign Affairs was considering introducing some modifications into the Gomułka Plan'.

${ }^{52}$ AMSZ 24/70, Information and auxiliary material sent on 2 [October 1965], in accordance with instructions by the Head of Department IV, M. Łobodycz, to the President of the Council of State's Chief of Staff, Head of the Department of the Central Committee of the Polish United Workers' Party, and the Secretariat of the Central Committee, comrade Zenon Kliszko, 2 October 1965. For more on Italy's ambitions to play a more substantial role in the East-West dialogue, see Silvio Pons, 'L'Italia e il PCI nella politica estera dell'URSS di Brežnev', in L'Italia Repubblicana nella crisi degli anni Settanta, 4 vols, Soveria Mannelli, 2003, vol. 1: Tra guerra fredda e distensione, ed. Agostino Giovagnoli and Silvio Pons, p. 68.

${ }^{53}$ Łoś-Nowak, Polskie inicjatywy, pp. 301-02. In late 1964 and early 1965 the Eigh- 
'attractiveness' to the Western public, it may have ceased to be an important propaganda instrument for Moscow. The growth of the Soviet nuclear potential at the time made the country an equal partner to Washington in discussions about non-proliferation of nuclear weapons. ${ }^{54}$

It is, therefore, not surprising that in the talks between Warsaw and its Western partners the issue in question, according to the Polish Ministry of Foreign Affairs, apparently came down to "continuing the discussion about and maintaining interest in the freezing of nuclear weapons by a variety of means' rather than implementing the country's own initiatives. ${ }^{55}$

This minimalist position was undoubtedly reflected in the Warsaw talks of the deputy Minister of Foreign Affairs Mario Zagari (23-26 March 1965) as well as the talks between the President of Poland's Council of State Edward Ochab and the President of the Italian Republic Giuseppe Saragat during his official visit to Poland in autumn 1965 (14-16 October) ${ }^{56}$ Both visits were a fiasco, demonstrating that the Italians had no intention of taking up the Polish initiatives and establish closer political relations with Warsaw. During his visit to Warsaw Zagari, referring to the Polish disarmament proposal, limited himself in his talks with Adam Rapacki and his deputy Marian Naszkowski to a vague statement that 'they are very well understood by the Italian people and are appreciated by the Italian government as an expression of efforts to ease tension'. The only concrete result the Polish side managed to obtain was a statement of the Italian government's readiness, expressed by the Italian diplomat, 'to continue dialogue, both during visits and through diplomatic channels'. Some hopes for dialogue in the matter were generated in Poland by a visit, announced by Zagari, of the Italian Minister of Foreign Affairs Fanfani, who was to accompany the President of Italy on his visit to Poland and in whom Warsaw placed its hopes for closer cooperation. ${ }^{57}$

teen Nation Committee on Disarmament tackled the problem of non-proliferation of nuclear weapons. On 24 September a draft document on non-proliferation of nuclear weapons was submitted by the USSR and on 17 August 1965 a proposal concerning this matter was put forward at the ENCD also by the USA.

${ }^{54}$ Soutou, La guerre de Cinquante Ans, pp. 458-59.

${ }^{55}$ AMSZ, file 24, folder 70, bundle 6, That is why the analysis conducted by the Ministry of Foreign Affairs' Department IV of the 'current state of talks and tactics in the matter of the Polish initiatives' rightly stressed the 'need to end the whole campaign and temporarily withdraw from talks about the matter'. Quoted after Łoś-Nowak, Polskie inicjatywy, p. 302.

${ }^{56}$ ACS, Aldo Moro, B. 81, Visita di Saragat a Varsavia, 14-16 ottobre 1965, no pagination.

${ }^{57}$ AMSZ 26/70, Urgent note by M. Naszkowski, Warsaw, 30 March 1965, no pagination. 
However the autumn visit by the head of the Italian Republic (Giuseppe Saragat) to Poland brought neither new impulses nor concrete results concerning closer collaboration between the two countries in this area. During an exchange of views with the President of the Council of State Ochab, who proposed a conference of European states that would tackle the problems of security and cooperation, the Italian President was, like Zagari, extremely reticent. He left his Polish interlocutor in no doubt as to his negative attitude concerning regional security plans. However, clearly wanting to soften his position, he stressed that he saw the question of the conference in a broader context of general security. 'A pan-European conference would be interesting,' he concluded, 'but only after detailed preparations and at the right moment'. ${ }^{58}$

It seems that the talks did not bring any important results and did not go beyond customary courtesy, ${ }^{59}$ as was reflected by the joint Polish-Italian communiqué. ${ }^{60}$

The position of Saragat himself on matters of disarmament and détente as well as the absence of the Minister of Foreign Affairs, Fanfani, during the president's autumn visit to Warsaw made the fiasco complete. ${ }^{61}$ It shattered the hopes for finding a quick iunctim and for a rapprochement between Warsaw and Rome on the basis of the so-called Fanfani Plan. This was also the tone of an assessment of the visit carried out by the Polish Ministry of Foreign Affairs, which pointed to the "toughening of Italian policy' against the background of the deteriorating international situation as well as the greater dependence of Italy's policy on the USA and pressure on the part of West Germany. ${ }^{62}$

That the Italians were not interested in the conference proposal is confirmed by an expost statement by Italy's Deputy Minister of Foreign Affairs,

${ }^{58}$ ACS, Aldo Moro, B. 81, Visita di Saragat a Varsavia, 14-15 ottobre 1965; AMSZ $43 / 70$, Notes on comrade Ochab's contribution during talks at the Belvedere [14 October 1965]; Saragat - [14 October 1965] no pagination; ibid., Saragat - 15 October 1965 (after address by comrade Ochab of 15 October 1965), no pagination.

${ }^{59}$ Bernatowicz sees the visit differently in terms of its results, see eadem, Stosunki polsko-włoskie, pp. 133-34.

${ }^{60}$ AMSZ 43/70, Communiqué on President Saragat's visit to Poland (published in Trybuna Ludu, 17 October, 1965, no. 243).

${ }^{61}$ AMSZ 23/69, Ambassador A. Willmann to M. Łobodycz, Rome, cable of 15 October 1964. As the Minister of Foreign Affairs, Saragat deluded Polish diplomats, stressing on each occasion that he 'ordered that the Polish plans for the zone be studied, without excluding a possible Italian initiative to support them', although he added that the Italians would not be able to act here - because of West Germany - 'as decisively and openly as they wanted'.

${ }^{62}$ AMSZ $43 / 70$, Note on the visit by the President of Italy, G. Saragat, to Poland, Warsaw, 30 October 1965, no pagination. 
Zagari, in a conversation with the Polish ambassador, Adam Willmann. He admitted that 'after Saragat's talks in Warsaw no one in Italy studied the question of the conference'. ${ }^{63}$

The hardening of Rome's position may have been influenced (in addition to Italy's unwillingness to become involved in unpromising contacts with Warsaw) also by the worsening climate in the contacts between the East and the West, especially after Leonid Brezhnev rejected West Germany's peace note (of 25 March 1966) at the 23rd Congress of the Communist Party of the Soviet Union. In its note of 24 March 1966, presented to the embassy of the Polish People's Republic in London, West Germany reiterated its legal position on the borders of the German state of 1937. The West German government proposed an exchange of notes concerning renunciation of violence. It also expressed its willingness to take part in a disarmament conference. The Bonn note was rejected by the government of the Polish People's Republic, which stressed in its reply the final form of the border on the Oder and the Neisse. ${ }^{64}$

A new impulse in Polish-Italian relations came only with a visit to Rome by the USSR's Minister of Foreign Affairs, Andrei Gromyko (21-27 April 1966), during which the Italian side expressed its readiness to continue the dialogue with the Soviet government in matters of détente, on the basis of the existing balance of power in Europe, and to expand (economic) cooperation with socialist countries. ${ }^{65}$

During talks with Gromyko, both Saragat and Fanfani expressed their positive opinion about the idea of organizing a meeting of European countries devoted to questions of security, stating that Italy could support the proposal, if it were put forward by a neutral European state (that is Switzerland, Sweden or Austria). The two Italian politicians presented themselves as advocates of an agreement on non-proliferation of nuclear weapons.

In addition, they spoke firmly against providing West Germany with access to these weapons. In the view of Soviet diplomats, this paved the way for a warming of the dialogue with Rome, especially as they also believed that the Italians sought to play a more substantial role on the international stage. Although the decision makers at the Polish Ministry of Foreign Affairs claimed that 'Italy is not yet prepared to run an independent campaign on a large international scale and will continue to look to

${ }^{63}$ AMSZ 43/70, A. Willmann to M. Naszkowski, Rome, cable of 31 May 1966, no pagination.

${ }^{64}$ Wojciech Roszkowski, Półwiecze. Historia polityczna świata po 1945 roku, Warsaw, 1997, p. 164.

${ }^{65}$ Pons, 'L'Italia e il PCI nella politica estera dell'URSS di Brežnev', p. 69. 
the USA and NATO', in conclusion they recommended a more active approach in relations with Italy, which 'seems beneficial and possible at present'. ${ }^{66}$

Although no NATO member state showed any special interest in the idea of the conference, Italy's attitude seemed conducive to continuing discussion on the matter. All the more so since the Polish diplomats designated to take part in the discussion at the ENCD forum informed their superiors that Italy might present a modified version of the so-called Fanfani Plan. ${ }^{67}$

The anticipated intensification of the activities of Italian diplomats seemed well in line with a resolution of the Warsaw Pact countries, passed at a conference in Bucharest (4-6 July 1966), concerning the 'easing of tension in Europe' through 'development of political, economic, cultural and scholarly contacts, and preventing West Germany from getting access to nuclear weapons'. There was emphasis on the fact that it would also lead to the organization of a security and cooperation conference. ${ }^{68}$

In this context Fanfani's proposal of a visit to Warsaw was important and 'attractive' enough for the Polish Ministry of Foreign Affairs to support the Italian initiative concerning his visit. An exchange of opinions as well as the prospect for possible cooperation may have seemed all the more interesting (and important also in terms of prestige) given that, as Warsaw suspected, Fanfani wanted to 'sound us out on how we will react to his concept'. Especially as the Polish side believed 'it was highly unlikely that in such a crucial matter [as a modification of the Fanfani Plan - M.P.] the Italians would put forward a proposal without the approval of the Americans'. ${ }^{69}$

However, taking into account the previous experiences in relations with Rome, expectations associated with the visit by the Italian Minister of

${ }^{66}$ AMSZ 43/70, Urgent note on the results of the visit by the USSR's Minister of Foreign Affairs, A. Gromyko, to Italy, passed by the Soviet embassy, Maria Vierna, to comrade M. Łobodycz, secret, Warsaw, 24 May 1966.

${ }^{67}$ AMSZ 43/70, Mieczysław Blusztajn to M. Naszkowski, Geneva, cable of 20 July 1966; ibid., Note by the Ministry of Foreign Affairs' Department of Research and Analysis, Warsaw, 25 July 1966. The modification of the Fanfani Plan was to consist in the moratorium covering all forms of non-proliferation (a concession to the socialist countries), provided the right to consultations about nuclear matters among the allies was recognized. The main objections of the socialist countries concerning the Fanfani Plan came down to the fact that in addition to a production ban the plan would ban only national control over nuclear weapons.

${ }^{68}$ Roszkowski, Pótwiecze, p. 163.

${ }^{69}$ AMSZ 43/70, Note by the Ministry of Foreign Affairs' Department of Research and Analysis, no pagination. 
Foreign Affairs, Fanfani, to Warsaw (25-27 July 1966) were moderate. The reasons included contradictory information coming from Rome's Polish embassy. On the one hand Ambassador Willmann informed the ministry that after Gromyko's visit to Rome and consultations with Belgium in the European Council as well as with the United Kingdom and Denmark, it was apparently suggested by his talks with the deputy minister, Zagari, that the Italians showed 'more interest in a European disarmament conference'. According to the same source, they also expressed their willingness to enter into a 'dialogue with Poland and study the Polish suggestions'. On the other hand the Polish Ministry of Foreign Affairs thought that Zagari's information might not necessarily reflect the position of Fanfani and the Italian government.

The Warsaw talks of Italy's Minister of Foreign Affairs with Minister Rapacki, President of the Council of State Ochab and Prime Minister Cyrankiewicz seemed to support this view. The Italian visitor did not reject the concept of partial disarmament steps, but he did not take up the idea of a more detailed discussion, proposed by Rapacki, ${ }^{70}$ about matters associated with the future conference, either in the context of the Polish disarmament initiative or of the Fanfani Plan.

The Italian foreign minister shied away from a more detailed discussion on the topic, letting his interlocutor know that the debate about the conditions for organizing the conference could not take place within the framework of bilateral relations. ${ }^{71}$ These tendencies could be seen in the joint Polish-Italian communiqué, which the two sides limited to a confirmation 'of their desire to achieve progress in the negotiations on complete and controlled disarmament' and of the informational nature of the visit. ${ }^{72}$

In light of the talks' aftermath, Minister Rapacki seems relatively accurate in the view he noted for the highest state and party authorities. Assessing the visit, Rapacki wrote that Fanfani had wanted to strengthen Italy's position vis-à-vis the West (especially the United States) ${ }^{73}$ by stressing the possibilities of Italy's foreign policy in relations with socialist countries and strengthening his personal position on the international stage as well as influence in the internal power struggle within

${ }^{70}$ AMSZ 43/70, A. Rapacki-A. Fanfani talks. Meeting of 25 July 1966, no pagination.

${ }^{71}$ Ibid.

72 AMSZ 43/70, Communiqué. The final text of a joint communiqué published in the press on 28 July 1966 , no pagination.

${ }^{73}$ Especially after France submitted an official motion to withdraw its troops from NATO's military structures (9 March 1966). France did remain within NATO's political structures. 
the Christian Democratic Party and Italy's centre left. ${ }^{74}$ It should be added that for the Polish side the results of the visit (as from the visit of President Saragat) were quite modest, limited as they were to an invitation extended to Minister Rapacki and the President of the Council of State Ochab to pay a state visit to Italy 'in order to continue the exchange of views'. ${ }^{75}$

The year 1967 was a time of more intense activity for the Polish diplomats, who, undeterred by their lack of success, began - after a conference of foreign affairs ministers of the Warsaw Pact countries (February 1967) and a declaration presented after a meeting of the leaderships of European communist parties in Karlovy Váry (25 April 1967) - to promote even more actively the idea of a European agreement on non-use of violence and non-aggression, seeing in this a means to maintain the status quo and to eliminate the West German threat. ${ }^{76}$

It might have seemed that a more fruitful dialogue with Rome on this matter and the opening of a new chapter in the relations between the Republic and countries from behind the Iron Curtain (especially after Gromyko's visit to Rome) would be facilitated by decisions taken by Aldo Moro's government, especially those of the Minister of Foreign Affairs Fanfani, seeking to pursue a more independent foreign policy. This was suggested in the tactics adopted with regard to Washington, manifested in the strategy of equal distance (equidistanza) from Israel and Arab countries, and a critical attitude to the bombing of North Vietnam by the USA. ${ }^{77}$

The way for a new opening in political contact between Warsaw and Rome was to have been paved by a visit by Edward Ochab, President of the Council of State to Italy (6-8 April 1967), as well as his talks at the Quirinale with President Saragat and at the Italian Ministry of Foreign Affairs. Despite expectations on the Polish side, this time too the Italian President confined himself to reiterating familiar generalities (for example about Italy's support for a nuclear non-proliferation agreement). Nor did any concrete results emerge from an exchange of views with Fanfani. The minister focused mainly on providing an extensive explanation of Italy's attitude to

${ }^{74}$ AMSZ 43/70, Urgent note [by A. Rapacki] about Minister Fanfani's visit to Poland (25-28 July 1966), Warsaw, 30 July 1966, no pagination.

${ }^{75} \mathrm{Cf}$. an assessment of the visits by G. Saragat and A. Fanfani, Bernatowicz, Stosunki polsko-włoskie, pp.133-34.

${ }^{76}$ Jarząbek, Polska wobec Konferencji Bezpieczeństwa i Współpracy, pp. 26-27; Roszkowski, Półwiecze, p. 165; Soutou, La guerre de Cinquante Ans, p. 475.

${ }^{77}$ Mammarella and Cacace, La politica estera dell'Italia, pp. 222-23. Italian politicians believed that a revival of German militarism could be prevented only by firmly anchoring West Germany in NATO and the European Economic Community. Italy supported the peace note of Chancellor Erhard's government of 25 March 1966. 
a nuclear non-proliferation agreement, stressing that Italy was in favour of an agreement that would be 'effective'. This 'effectiveness' or, in fact, different understanding of the criterion of effectiveness and the control system associated with it, proved to be the main obstacle to achieving a rapprochement. Doubts were generated by the political objectives of a future agreement, especially the most important objective for the Poles, namely not providing West Germany with access to nuclear weapons (thereby strengthening its position), which the Italian side clearly did not want to appreciate, adopting a stance that was in line with Bonn's goals. ${ }^{78}$

It seems that the Poles were not satisfied with Fanfani's declarations concerning Italy's readiness to cooperate with socialist countries in economic, cultural, scientific... and even political matters, cooperation to facilitate 'finding analogous solutions to bigger problems (that is détente) of global scale, problems yet to be resolved', or with enigmatically expressed intentions to 'open a dialogue in the spirit of cooperation and maintenance of peace'. ${ }^{79}$

Warsaw's negative view of the so-called Fanfani $\mathrm{Plan}^{80}$ as well as Rome's obstructive (in Poland's perception) stance during a session of the Eighteen Nation Committee in Geneva, where Italy (like West Germany) expressed its reservations about an agreement on non-proliferation of nuclear weapons made it practically impossible to find a modus vivendi during talks at the Farnesina about a nuclear non-proliferation agreement and a future conference on security and cooperation in Europe. ${ }^{81}$ This last issue was treated by the hosts as a marginal one. Limiting themselves to the

${ }^{78}$ AMSZ 4/71, Urgent note by M. Naszkowski, approved by E. Ochab, on the visit to Italy, Warsaw, 14 April 1967; ACS, Aldo Moro, B. 68, MAE, G. Pompei, capo di Gabinetto del Ministro degli Affari Esteri (A. Fanfani) al presidente del Consiglio dei Ministri, A. Moro, Roma, 6 aprile 1967.

${ }^{79}$ ACS, Aldo Moro, B. 68, MAE, G. Pompei, capo di Gabinetto del Ministro degli Affari Esteri (A. Fanfani) al presidente del Consiglio dei Ministri, A. Moro, Roma, 6 aprile 1967.

${ }^{80}$ AMSZ 4/71, Information material in connection with a visit by the President of the Council of State, E. Ochab, to Italy, 6-8 April 1967. The Polish Ministry of Foreign Affairs viewed the so-called Fanfani Plan as 'unacceptable' for the following reasons: limiting the obligations of non-nuclear states to simply renouncing national control provided for a possibility of co-ownership of and co-decision about nuclear weapons within the MLF, thus it would not prevent West Germany from gaining access to these weapons. All signatories (including West Germany) would have been free to act even before the expiry of the moratorium, if in the meantime any non-nuclear state had gained control over nuclear weapons.

${ }^{81}$ Ibid. According to Fanfani's chief of staff, the Italians' concerns over a non-proliferation treaty stemmed from, among others, the fear in Italian industrial circles that the treaty would have adverse repercussions by halting technological progress in Italy. 
statement that Italy supported the idea of the conference (featuring the USA and (anada) and that the problem required further study, they made it clear to the Polish side that Moscow, as in their view the author of the conference's proposal, and not Warsaw should be their partner in discussion about the matter. ${ }^{82}$

That is why despite the propaganda publicity given the visit to Italy, it did not fulfil Warsaw's hopes for winning acceptance towards Poland's most important objective, or for the efforts of the Polish diplomats to ensure security vis-à-vis Germany and consolidate Poland's western border. ${ }^{83}$ Support for the idea of a security conference and for the 'need to prepare it appropriately' (which in practice indicated a remote date for the conference and which was stressed in the joint communiqué) was by and large the only point agreed on by the two sides. ${ }^{84}$

The intervention of the Warsaw Pact countries in Czechoslovakia in August 1968 led to a cooling of the East-West relations, although it did not put an end to disarmament talks in the long run. Nor were relations with Western European countries (including Italy) affected to any great extent by the turbulence in Poland (March 1968, including a purge at the Polish Ministry of Foreign Affairs and the departure of Rapacki from the ministry). ${ }^{85}$

However, the invasion of Czechoslovakia by the Warsaw Pact troops (20/21 August 1968) mobilized the Italian public, as well as groups hostile to an expansion of contacts with Eastern Bloc countries, which led to a temporary hardening of the foreign policy of Giovanni Leone's Christian Democratic government (June 1968-December 1968). Leone tried to leverage the situation to weaken the influence of the communist opposition and neutralize the left wing of the Christian Democrats opposing a confrontation between the two blocs. This stance, as well as the conviction present in most political circles that negotiations over security and cooperation in Europe should be continued, prevailed in Mariano Rumor's new centre-left government, in which the office of

${ }^{82}$ AMSZ 4/71, Urgent note by M. Naszkowski, approved by E. Ochab, on the visit to Italy, Warsaw, 14 April 1967, no pagination.

${ }^{83}$ AMSZ 4/71, Urgent note. Echoes of the visit by the President of the Council of State [E. Ochab] in the light of statements and press accounts, Warsaw, 26 April 1967, no pagination.

${ }^{84}$ Joint Polish-Italian communique on the state visit by the President of the Council of State of the Polish People's Republic, E. Ochab, to Rome, Trybuna Ludu of 8 April 1967, quoted after Bernatowicz, Stosunki polsko-włoskie, p. 135. Bernatowicz views the visit differently. See eadem, Stosunki polsko-włoskie, p. 135.

${ }^{85}$ Jarząbek, Polska wobec Konferencji Bezpieczeństwa i Wspótpracy, p. 33. 
the Minister of Foreign Affairs was entrusted to the Socialist Pietro Nenni. ${ }^{86}$

This is evidenced, for example, by Prime Minister Rumor's policy statement, in which he generally supported (although in a longer term) the idea of organizing a security conference featuring the USA. ${ }^{87}$ The mood within the Italian government in this matter was also reflected in a statement of the newly elected (after the June 1968 election) President of the Senate, Fanfani during talks with the Polish ambassador in Rome, Wojciech Chabasiński. Referring to the events in Czechoslovakia, Fanfani said that 'Italy should work on détente in Europe and not help, even unknowingly, entities breaking the unity of socialist countries' ${ }^{88}$ What became a litmus test of the intentions of Rumor's government in this area was the signing by Italy (on 28 January 1969) of a nuclear non-proliferation treaty, delayed by the previous government which feared the possiblility of a negative reaction from West Germany. ${ }^{89}$

A strategic situation in which Moscow found itself facing tension in the Soviet-Chinese relations (February 1969), as well as its own desire to consolidate its position in Europe (by maintaining the status quo), prompted the Kremlin to become involved in negotiations aimed at reducing strategic weapons. A signal of Moscow's new direction in this respect, including the desire to improve its international image after the invasion of Czechoslovakia, came in the form of the so-called Budapest Appeal adopted by the Political Consultative Committee of the Warsaw Pact countries (on 17 March 1969). ${ }^{90}$ The document testified to

${ }^{86}$ AMSZ 23/76, bundle 8, Note [signed by Head of Department IV, A. Willmann] for Minister S. Jędrychowski in connection with an upcoming visit by the Italian ambassador M. Castronuovo, Warsaw, 11 April 1969.

${ }^{87}$ Stefan Rudnik, Stosunki polsko-włoskie w latach 1945-1975, Słupsk, 1978, p. 74.

${ }^{88}$ AMSZ 23/76, bundle 8, Political note no. 3/69. [W. Chabasiński's] talks with the new President of the Senate, Senator A. Fanfani, Rome, 15 January 1969. Fanfani also said that the ' $C$ zech episode is closed as far as he was concerned'.

${ }^{89}$ The Treaty on the Non-Proliferation of Nuclear Weapons was signed by the USSR, USA and United Kingdom on 1 July 1968. Entering it into force depended on the submission of ratification documents by 40 states - the signatories and the above superpowers. Leone's government delayed the signing of the treaty, using the invasion of Czechoslovakia by the USSR and Warsaw Pact countries as a pretext. The West German government did not sign the treaty until 28 November 1969. Łoś-Nowak, Polskie inicjatywy, p. 305.

90 The Budapest Appeal endorsed the Soviet proposal to organize a disarmament conference, stressing that security in Europe was based on the inviolability of the existing borders, including the border on the Oder and the Neisse as well as the border between the two German states. See Jarząbek, Polska wobec Konferencji Bezpieczeństwa i Współpracy, pp. 38-39, 40-41; Georges-Henri Soutou, 'L'attitude de Georges Pompidou face à l'Allemagne', in Georges Pompidou et l'Europe, Brussels, 1995, p. 282. 
a clash of interests within the Eastern Bloc, where the priorities of the Polish People's Republic did not always overlap with those of the USSR and other socialist countries. ${ }^{91}$ When it came to Italy, some hopes for an evolution in the country's foreign policy (not only in matters of security) were associated with the foreign minister, Nenni. ${ }^{92}$ The positive response to the Budapest Appeal among the Italian Socialists could, so it was expected, lead to a change in the attitude of the centre-left government towards the idea of a European security conference. ${ }^{93}$ The Italian foreign minister not only expressed his support for the suggestion during a session of the NATO Council in Washington (in April 1969), but was apparently instrumental in formulating the proposals in the final communique of the session, that provided a way of starting negotiations with the Eastern Bloc. ${ }^{94}$ According to the Italian ambassador to Poland, Manlio Castronuovo, Nenni's contribution in Washington went the furthest in responding to the initiative of the socialist countries, while the Italian government, in the diplomat's view, 'has always supported co-existence and cooperation' and confirmed this stance also after the events in Czechoslovakia. ${ }^{95}$ However, Castronuovo's conclusion concerning the intentions of the Italian minister was received with considerable scepticism by the new Minister of Foreign Affairs, Stefan Jędrychowski. ${ }^{96}$

According to the Polish embassy in Rome, Nenni's proposal (endorsed by the Italian government), presented at the NATO session in Washington and then to the Council of Europe's Assembly in Strasbourg (13 May 1969)

91 The Polish diplomats' struggle with the USSR and attempts to formulate a common position by the Eastern Bloc have been extensively discussed by Jarząbek, Polska wobec Konferencji Bezpieczeństwa i Wspótpracy, pp.39-66.

${ }^{92}$ AMSZ 23/76, bundle 8, Note [signed by Head of Department IV, A. Willmann] for Minister S. Jędrychowski in connection with an upcoming visit by the Italian ambassador M. Castronuovo, Warsaw, 11 April 1969. Nenni announced the recognition of the People's Republic of China, establishment of diplomatic relations with the country (and its admission to the UN) as well as examination of the question of recognition of the Democratic Republic of Vietnam.

${ }^{93}$ Ibid.

${ }^{94}$ Rudnik, Stosunki polsko-włoskie, pp. 73-79.

${ }^{95}$ AMSZ 23/76, bundle 8, Urgent note by S. Jędrychowski on a conversation with the Italian ambassador in Warsaw, M. Castronuovo, Warsaw, 14 April 1969. Rudnik, Stosunki polsko-włoskie.

${ }^{96}$ AMSZ 23/76, bundle 8, Urgent note by S. Jędrychowski on a conversation with the Italian ambassador in Warsaw, M. Castronuovo, Warsaw, 14 April 1969. During talks with the ambassadors of the USSR and Hungary to Rome concerning a security conference Nenni demanded a guarantee of the USA's participation in the conference as well as restoration of normalization in Czechoslovakia in the sense of a 'return to the status quo ante', a stance viewed with disapproval by his interlocutors, who opted for the conference without any preconditions. 
was markedly different from those put forward by the socialist countries in the Budapest Appeal. The two sides differed when it came to the date of the security conference, its agenda as well as its objective and central focus. ${ }^{97}$ The Warsaw-Rome dialogue concerning the future conference was not endorsed by the opinion of the socialist countries' diplomatic corps in Rome. According to the Polish embassy, the diplomats agreed that Nenni's proposals in this area were not very constructive and were based on ideological premises that had nothing in common with the essence of the socialist countries' proposals included in the Budapest Appeal..$^{98}$ This was the tenor of conclusions from Ambassador Chabasiński's talks with the Undersecretary of State at the Italian Ministry of Foreign Affairs Mario Pedini, who claimed that a European security conference was not a priority for Italy, as the country's focus lay on the Mediterranean and Adriatic Seas. ${ }^{99}$ In any case, Warsaw was unable to win Moscow's support for its proposals to develope broader economic cooperation with the West as well as a security programme that would involve all Eastern Bloc countries. ${ }^{100}$ The organization of the conference was hindered also by the NATO countries' restrained response to the Eastern Bloc's proposals (expressed at a meeting of the Atlantic Council in Brussels). The NATO countries were interested in comprehensive security within Europe and not in the propaganda effects of a future conference, which was the Kremlin's most important objective. ${ }^{101}$ In such a situation further steps to establish closer cooperation with Italy were doomed to

${ }^{97}$ AMSZ 23/76, bundle 8, Embassy of the Polish People's Republic in Rome, 'Pietro Nenni's concept in Italy's foreign policy with regard to selected issues', [drafted by Kazimierz Szablewski, titular counsellor of the Embassy] W. Chabasiński to Head of Department IV, A. Willmann, Rome, 25 July 1969. According to Nenni, the ultimate goal of the East-West dialogue should be the creation of an appropriate European security system based on the right of nations to independence, freedom and full sovereignty. In Nenni's view this goal could not be achieved immediately. Needed was a preparatory period divided into stages, beginning from an agreement in the fields of culture, trade, tourism, science and technology.

${ }^{98}$ Ibid. The same document stated that Nenni's concepts served to 'weaken and disintegrate the unity of the socialist community'.

${ }^{99}$ AMSZ 23/76, bundle 8, Political note by the Polish ambassador, W. Chabasiński, Rome, 24 October 1969.

${ }^{100}$ Wanda Jarząbek was right in saying that Moscow 'wanted to play the role of a centre regulating and rationing contacts with the West', seeing the possibility of broader cooperation between the socialist countries and the West as a way to reduce the former's dependence on the USSR. Jarząbek, Polska wobec Konferencji Bezpieczeństwa i Wspótpracy, pp. $62 \mathrm{ff}$.

${ }^{101}$ NATO's position was expressed in the Declaration of the North Atlantic Council issued on 9 December 1969. Jarząbek, Polska wobec Konferencji Bezpieczeństwa i Wspótpracy, pp. 74-76; Soutou, La guerre de Cinquante Ans, pp. 532-33. 
failure. Once again it turned out that initiatives of medium-sized and small states stood no chance of success, and that such countries' foreign policies could not go beyond the boundaries of the blocs within which they found themselves.

(Translated by Anna Kijak)

(Proofreading by Yelizaveta Crofts)

\section{Summary}

Between 1958 and 1969 the governments of the Italian Republic were reluctant to support the Rapacki Plan (1957) and the Gomulka Plan (1963) put forward by the Polish People's Republic. The negative attitude to these proposals stemmed primarily from political considerations, from a conviction that the most important problems on the international stage at a time of a cold war and binary division of the world were determined by Moscow and Washington, while medium-sized states (like Italy) had to give up any great political ambitions. Strategic and military decisions taken by NATO were accepted and implemented by Rome. In the view of the Italian establishment, détente between the USSR and the USA could lead to a reduction of the American presence on the European continent and the Italian Peninsula as well as a reduction in the USA's economic, military and financial aid for Italy. This would expose Italy not only to a military threat from the 'socialist camp' but also to political instability, which could lead to a takeover of power by the Italian Communist Party. That is why in the view of Italian government circles the greatest danger associated with the plans put forward by Polish diplomats stemmed not from their military premises but from political and propaganda considerations. According to the government, the Rapacki Plan and then the Gomułka Plan were a way of solving the problem of the Polish border on the Oder and the Neisse as well as of weakening NATO, which was unacceptable.

(Translated by Anna Kijak)

(Proofreading by Yelizaveta Crofts)

\section{Bibliography}

Albrecht, Ulrich, 'The Political Background of the Rapacki Plan of 1957 and Its Current Significance', International Journal of Politics, 13, 1983, 1/2, pp. 117-33. Bernatowicz, Grażyna, Stosunki polsko-włoskie 1944-1989, Warsaw: Polski Instytut Spraw Międzynarodowych, 1990.

D’Amoja, Fulvio, 'Piano Rapacki e rapporti fra i due blocchi', La Comunità Internazionale, 14, 1959, 4, pp. 604-25.

Długołęcki, Piotr, 'Nieznany kontekst planu Rapackiego', Sprawy Międzynarodowe, 64, 2011, 1, pp. 116-27. 
Gierowski, Józef Andrzej, Historia Włoch, Wrocław: Zakład Narodowy im. Ossolińskich, 1985.

Heuser, Beatrice, NATO, Britain, France and the FRG. Nuclear Strategies and Forces for Europe, 1949-2000, London and New York: Macmillan, 1997.

Jarząbek, Wanda, Polska wobec Konferencji Bezpieczeństwa i Wspótpracy w Europie. Plany i rzeczywistość 1964-1975, Warsaw: Instytut Studiów Politycznych Polskiej Akademii Nauk, 2008.

Kupiecki, Robert, Siła i solidarność. Strategia NATO 1949-1989, Warsaw: Polski Instytut Spraw Międzynarodowych, 2012.

Łoś-Nowak, Teresa, Plan Rapackiego a bezpieczeństwo europejskie, Wrocław: Wydawnictwo Uniwersytetu Wrocławskiego, 1991.

Łoś-Nowak, Teresa, Polskie inicjatywy w sprawie broni nuklearnej w Europie środkowej 1957-1964, Wrocław: Wydawnictwo Uniwersytetu Wrocławskiego, 1989.

Madajczyk, Piotr, 'Dyplomacja polska w latach sześćdziesiątych', in Historia dyplomacji polskiej, 6 vols, Warsaw: Polskie Wydawnictwo Naukowe; Wydawnictwo Naukowe PWN; Polski Instytut Spraw Międzynarodowych, 1980-2010, vol. 6: 1944/45-1989, ed. Wojciech Materski and Waldemar Michowicz, pp. 584-661.

Madajczyk, Piotr, 'Próby wznowienia Planu Rapackiego przez dyplomację polską w pierwszej połowie lat sześćdziesiątych', Rocznik Polsko-Niemiecki, 17, 2009, pp. 11-28.

Mammarella, Giuseppe, L'Italia contemporanea 1943-2007, Bologna: Il Mulino, 2008.

Mammarella, Giuseppe, and Paolo Cacace, La politica estera dell'Italia. Dallo Stato unitario ai giorni nostri, Rome and Bari: Laterza, 2010.

Mourlane, Stéphane, 'La France, l'Italie et la construction européenne: le temps des malentendus (1958-1965)', Relations internationales, 118, 2004, pp. 199-213.

Ozinga, James R., The Rapacki Plan. The 1957 Proposals do Denuclearize Central Europe, and Analysis of its Rejection, Jefferson, NC, and London: McF arland \& Company, 1989.

Pasztor, Maria, 'Francja i Wielka Brytania wobec polskich koncepcji rozbrojeniowych 1957-1964', Dzieje Najnowsze, 35, 2003, 1, pp. 85-111.

Pasztor, Maria, and Dariusz Jarosz, Skazani na podległość. Z dziejów stosunków polsko-włoskich w latach 1945-1958, Warszawa: Oficyna Wydawnicza ASPRA-JR, 2013.

Pons, Silvio, 'L'Italia e il PCI nella politica estera dell'URSS di Brežnev', in L'Italia Repubblicana nella crisi degli anni Settanta, 4 vols, Soveria Mannelli: Rubbettino, 2003, vol. 1: Tra guerra fredda e distensione, ed. Agostino Giovagnoli and Silvio Pons, pp. 63-87.

Roszkowski, Wojciech, Półwiecze. Historia polityczna świata po 1945 roku, Warsaw: Wydawnictwo Naukowe PWN, 1997.

Ruchniewicz, Krzysztof, Warszawa - Berlin - Bonn. Stosunki polityczne 1949-1958, Wrocław: Wydawnictwo Uniwersytetu Wrocławskiego, 2003.

Rudnik, Stefan, Stosunki polsko-włoskie w latach 1945-1975, Słupsk: Wyższa Szkoła Pedagogiczna w Słupsku, 1978.

Schwartz, David N., 'The Role of Deterrence in NATO Defense Strategy. Implications for Doctrine and Posture', World Politics, 28, 1975, 1, pp. 118-33. 
Skrzypek, Andrzej, Mechanizmy autonomii. Stosunki polsko-radzieckie 1956-1965, Pułtusk: Wyższa Szkoła Humanistyczna imienia Aleksandra Gieysztora w Pułtusku; Warsaw: Oficyna Wydawnicza ASPRA-JR, 2005.

Soutou, Georges-Henri, La guerre de Cinquante Ans. Les relations Est-Ouest 1943-1990, Paris: Fayard, 2001.

Soutou, Georges-Henri, L'alliance incertaine. Les rapports politico-stratégiques franco-allemands, 1954-1996, Paris: Fayard, 1996.

Soutou, Georges-Henri, 'L'attitude de Georges Pompidou face à l'Allemagne', in Georges Pompidou et l'Europe, ed. Jean-René Bernard et al., Brussels: Complexe, 1995, pp. 282-99.

Soutou, Georges-Henri, 'Les accords de 1957 et 1958: vers une communauté stratégique et nucléaire entre la France, l'Allemagne et l'Italie?', Matériaux pour l'Histoire de notre Temps, 31, 1993, pp. 1-12.

Tebinka, Jacek, 'Dyplomacja popaździernikowa (1957-1960). 1. Plan Rapackiego', in Historia dyplomacji polskiej, 6 vols, Warsaw: Polskie Wydawnictwo Naukowe; Wydawnictwo Naukowe PWN; Polski Instytut Spraw Międzynarodowych, 19802010, vol. 6: 1944/45-1989, ed. Wojciech Materski and Waldemar Michowicz, pp. 468-80.

Tebinka, Jacek, Nadzieje i rozczarowania. Polityka Wielkiej Brytanii wobec Polski 19561970, Warsaw: Wydawnictwo Neriton; Instytut Historii PAN, 2005.

Tyszkiewicz, Jakub, Rozbijanie monolitu. Polityka Stanów Zjednoczonych wobec Polski 1945-1988, Warsaw: Wydawnictwo Naukowe PWN, 2015.

Varsori, Antonio, L'Italia nelle relazioni internazionali. Dal 1943 al 1992, Rome and Bari: Laterza, 1998.

Wandycz, Piotr Stefan, 'Adam Rapacki and the European Security', in The Diplomats 1939-1979, ed. Gordon A. Craig and Francis L. Loewenheim, Princeton, NJ: Princeton University Press, 1994, pp. 289-317.

Biography: Maria Pasztor - Professor, member of the academic staff of the Institute of International Relations (Faculty of Political Science and International Studies, University of Warsaw). Research interests: history of international relations in the twentieth century, history of France and Italy in the twentieth and twenty-first centuries. Contact: g.pasztor@uw.edu.pl. 